\title{
Damages to unreinforced masonry buildings by the Van earthquakes of 23 October and 9 November 2011
}

\author{
Y. S. Tama ${ }^{1}$, A. Solak ${ }^{2}$, N. Çetinkaya ${ }^{1}$, G. Şen ${ }^{3}$, S. Yılmaz ${ }^{4}$, and H. Kaplan ${ }^{1}$ \\ ${ }^{1}$ Department of Civil Engineering, Pamukkale University, Kınıklı, Denizli, Turkey \\ ${ }^{2}$ Institute of Natural Sciences, Pamukkale University, Kınıklı, Denizli, Turkey \\ ${ }^{3}$ Department of Civil Engineering, İnönü University, Malatya, Turkey \\ ${ }^{4}$ Department of Civil Engineering, İzmir Katip Çelebi University, İzmir, Turkey
}

Correspondence to: Y. S. Tama (ystama@pau.edu.tr)

Received: 17 October 2012 - Published in Nat. Hazards Earth Syst. Sci. Discuss.: -

Revised: 11 January 2013 - Accepted: 15 January 2013 - Published: 13 February 2013

\begin{abstract}
Van, a city in Eastern Anatolian Turkey, was hit by two earthquakes with magnitudes of $M_{\mathrm{w}}=7.2$ and $M_{\mathrm{w}}=$ 5.6 in October and November 2011. Both earthquakes caused extensive damage to many buildings. Unreinforced masonry buildings, especially in rural areas, suffered from those earthquakes extensively as in many other cases observed in Turkey during other previous earthquakes. This paper presents a site survey of damaged masonry buildings. Reasons for the wide spread damages are discussed in the paper.
\end{abstract}

\section{Introduction}

Many people are living in unreinforced masonry (URM) structures, which constitute an important percentage of the building stock in Turkey. URM structures located on seismically active regions of Turkey are mainly non-engineered, deficient buildings. They have shown poor performance during many previous earthquakes. Damages to those buildings have caused many casualties and economic losses. Significant earthquake engineering lessons have been learned from surveys of these damaged buildings (Bayraktar et al., 2007; Korkmaz et al., 2010).

An earthquake of magnitude 7.2 occurred at 13:41 (local time) on 23 October 2011 (KOERI, 2011) in Van, which is located in east Anatolia in Turkey. After 17 days, a smaller magnitude earthquake $\left(M_{\mathrm{w}}=5.6\right)$ occurred at 21:23 (local time) on 9 November 2011 (KOERI, 2011) in the same region (Fig. 1). More than 2300 buildings collapsed in the first earthquake and in the second earthquake a small number of buildings which had already been damaged in the first earthquake also collapsed. It has been reported that most of the damage was due to the effect of the first earthquake and that approximately 2200 of the damaged buildings were in rural areas (Kizılkanat et al., 2011). Almost all of these buildings were URM structures in accordance with the typical building stock of the region. It was reported that 644 people died and approximately 4000 people injured by the two earthquakes (AFAD, 2011; Kizılkanat et al. 2011).

Characteristics of the earthquake are described and damage patterns and reasons for the extensive damages on URM buildings are presented in this paper. Many of the damaged buildings were unreinforced stone masonry having low construction quality.

\section{Seismological issues}

Van city center and Erciş district observed severe damage due to two earthquakes with magnitudes of $M_{\mathrm{W}}=7.2$ and $M_{\mathrm{W}}=5.6$ in October and November, 2011. The 23 October 2011 Van earthquake $\left(M_{\mathrm{w}}=7.2, \mathrm{KOERI}\right)$ is among the 10 highest magnitude earthquakes that have occurred in the last century in Turkey. Epicenters of these two earthquakes and distances to the regions damaged are shown in Fig. 1. It is indicated by METU-EERC (2012) that each of these two sequential earthquakes had different fault mechanisms. The seismological data related with the earthquakes obtained from KOERI is shown in Table 1.

The Eastern Anatolian Tectonic Region has been the site of many historical earthquakes. An important historical 
Table 1. 23 October and 9 November 2011 Van Earthquakes' seismological parameters reported by KOERI (2011).

\begin{tabular}{lllllll}
\hline Institution & Date & $\begin{array}{l}\text { Time } \\
(\mathrm{GMT})\end{array}$ & $\begin{array}{l}\text { Epicenter } \\
\text { Latitude }\end{array}$ & $\begin{array}{l}\text { Epicenter } \\
\text { Longitude }\end{array}$ & $\begin{array}{l}\text { Depth } \\
(\mathrm{km})\end{array}$ & $M_{\mathrm{W}}$ \\
\hline KOERI & 23 October 2011 & $10: 41: 21$ & 38.758 & 43.360 & 5 & 7.2 \\
KOERI & 9 November 2011 & $19: 23: 21$ & 38.429 & 43.234 & 5 & 5.6 \\
\hline
\end{tabular}

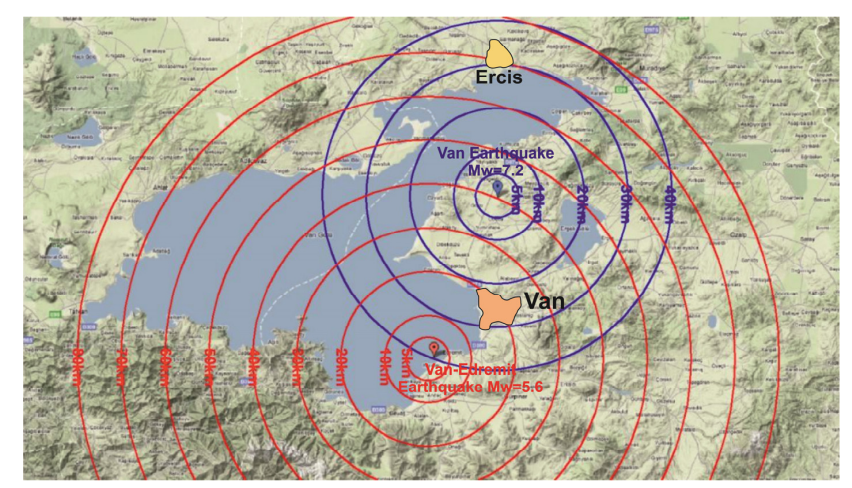

Fig. 1. Van and Van-Edremit earthquakes distance to epicenter (Önen et al., 2011).

earthquake occurred on 3 October 1275 (or 3 October 1276 according to Ambraseys, 2009) on the north side of Van lake (Guidoboni and Comastri, 2005; Albini, 2011). This earthquake affected Erciş and Ahlat districts and caused heavy damages. Another known earthquake occurred on 31 March 1648 and caused serious damages in Van city (Berberian, 1997). The Malazgirt earthquake that occurred on 28 April 1903 caused serious damages around the settlements on the north and west of Van Lake (Karnik, 1969).

\section{Geological and geotechnical issues}

The Lake Van basin is surfaced with metaformic rocks belonging to Bitlis Massive (Ketin, 1947; Helvaciand Griffin, 1984; Y1lmaz et al., 1981, 1993, 1998; Ustaömer et al., 2009; Oberhänsli et al., 2010) at the south of Lake Van basin, volcanic and volcanoclastic rocks coming from Nemrut and Süphan Mountains at the west and north, volcanic rocks and ofiyolit compounds from Yüksekova complex at the east, current river and lake deposits, and carbonates (Fig. 2).

In the map of active faults in the Van region prepared by Bozkurt (2001), as shown in Fig. 3, no active faulting is seen at the epicenter of the Van 2011 earthquake. Özkaymak (2003) has indicated the existence of active faults and young tectonic formations and that the tectonic marks in the region are in parallel with the regime of compression in a north-south direction. The occurrence of serious earthquakes in the region is possibly explained by these observations.
Fine to medium or rarely thick layers of sandstones and thin layer slopes are observed in the Van Formation which is formed generally from clastic rocks (Aksoy, 1988).

Celebi et al. (2011) detected sand cones, traces of lateral spreading and landslides in the observations made in Topaktaş village (Van, City Center) one week after the earthquake.

The main shock of the Van 2011 earthquake was recorded at the 22 stations of the National Strong Motion Network. During the main shock, acceleration records close to the assumed fault source could not be obtained since the Van Strong Motion Station was not recording at the time. Nonetheless, Muradiye Strong motion station records, which show similar soil properties, were used for the evaluations (Table 2). Comparison of the response spectra of VanErciş Muradiye and Van-Edremit earthquakes is shown in Fig. 4.

\section{Damages to URM buildings}

URM buildings are usually constructed from locally available construction materials in the countryside of Van Province. Masonry construction technique is similar in rural settlement areas at the disaster region. Most of the affected buildings were one-storey and had a heavy roofing of a thick composite slab made from mud and timber. This type of heavy roofing significantly increases the seismic base shear demand. Those non-engineered URM buildings were not earthquake resistant and were not in compliance with Turkish Seismic Codes (MPW, 1975; MPW, 1998; MPW, 2007). Various types of damages are exemplified in Fig. 5.

Many URM buildings were heavily damaged or collapsed in the region. Besides, a considerable number of them had some level of damage due to bad local construction practice. The disaster area was surveyed by our research team and detailed studies were carried out on the damaged buildings. During the investigations, the main reasons for the poor performance of URM buildings were determined. Use of improper masonry units, formation of inappropriate wall cross sections, inadequate or no connection of crossing walls, irregular wall openings and improper roofing are in the most important place. Most of those deficiencies initiated out of plane failures. The aforementioned deficiencies are illustrated below and their consequences are discussed in detail. 
Table 2. Characteristics of earthquake records used for the evaluation of Van earthquakes (Önen et al., 2011).

\begin{tabular}{llllll}
\hline Earthquakes & Record date & $\begin{array}{l}\text { Recorded station } \\
\text { (coordinates) }\end{array}$ & $\begin{array}{l}\text { Effective } \\
\text { record } \\
\text { Time (s) }\end{array}$ & $\begin{array}{l}\text { PGA } \\
\left(\mathrm{cm} \mathrm{s}^{-2}\right) \\
\text { NS, EW, Vertical }\end{array}$ & $\begin{array}{l}\text { PGV } \\
\left(\mathrm{cm} \mathrm{s}^{-1}\right) \\
\text { NS, EW, Vertical }\end{array}$ \\
\hline Van-Erciş & 23 October 2011 & Muradiye & $38.85(\mathrm{NS})$ & 195.49 & 26.95 \\
& $13: 41: 20$ & Meteorology & $22.29(\mathrm{EW})$ & 167.18 & 17.45 \\
& & $(38.68 \mathrm{~N}-43.46 \mathrm{E})$ & & 80.51 & 6.22 \\
\hline Van-Edremit & 9 November 2011 & Edremit TOKI & $17.57(\mathrm{NS})$ & 69.28 & 118.59 \\
& $21: 23: 33$ & $(38.44$ N-43.26E) & $34.58(\mathrm{EW})$ & 103.08 & 137.70 \\
& & & 44.85 & 43.53 \\
\hline
\end{tabular}

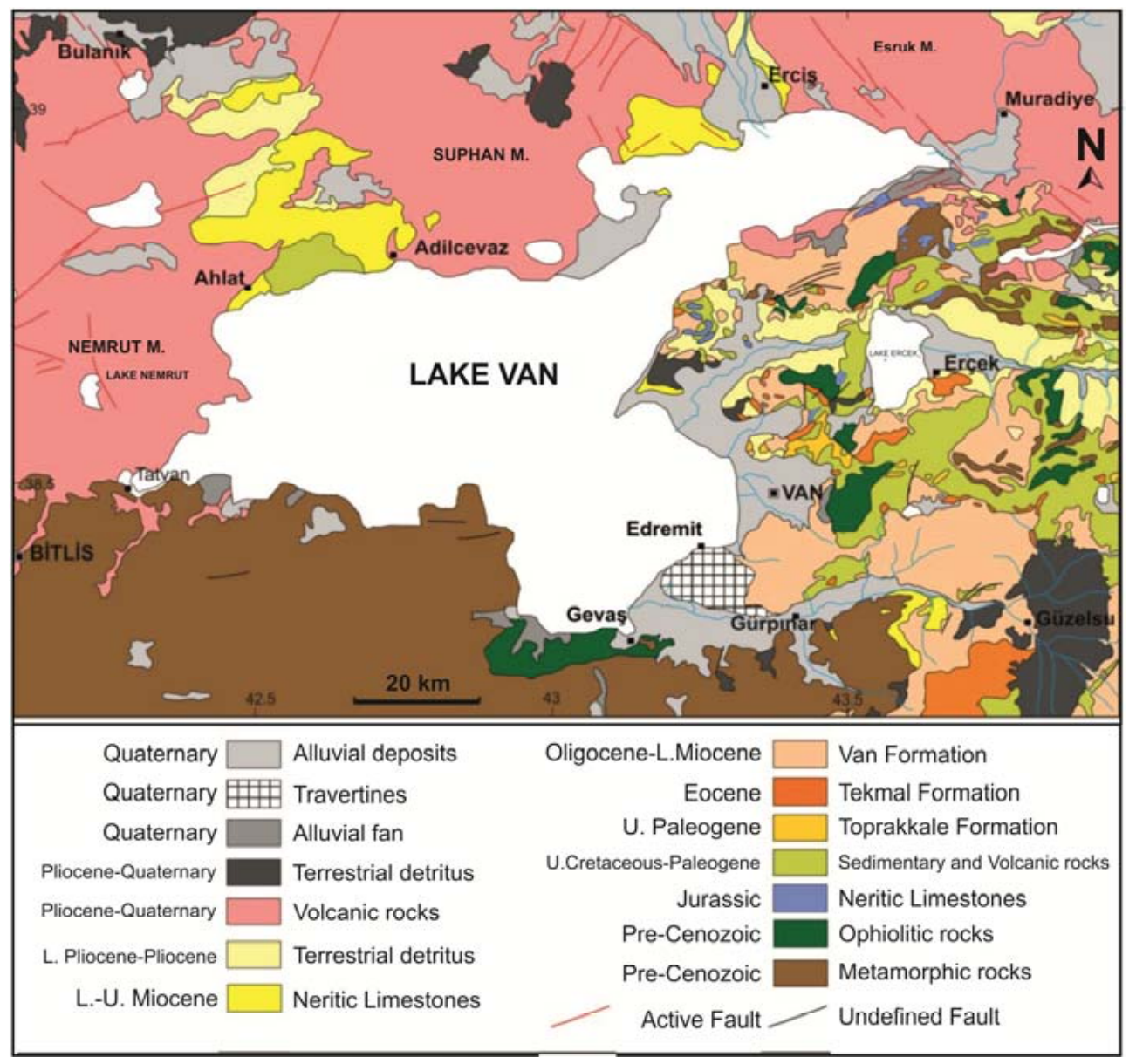

Fig. 2. Geological map of Lake Van and the surrounding area (MTA, 2002).

\subsection{Wall materials and wall cross section}

Use of improper masonry units is one of the most common deficiencies of the URM buildings in the disaster area. Adobe or stone constructions were very common. Sometimes improper briquettes and bricks with large holes were used as wall materials. Stone blocks were available in the nature as a wall material, but they usually have sphere-like shapes. However, stone used in wall construction should have pris- matic shapes, with parallel surfaces. In most of the investigated cases, stone blocks do not have a proper shape to be as a masonry wall material. Walls were usually formed by varying sizes of stone blocks. In the region, walls were composed of an inner and an outer wythe. However, configuration of those without interlocking elements causes both wythes to behave as independent walls, where the net length of the outer wythes of walls was considerably greater than the inner. Therefore, outer wythes become more prone to out-of- 


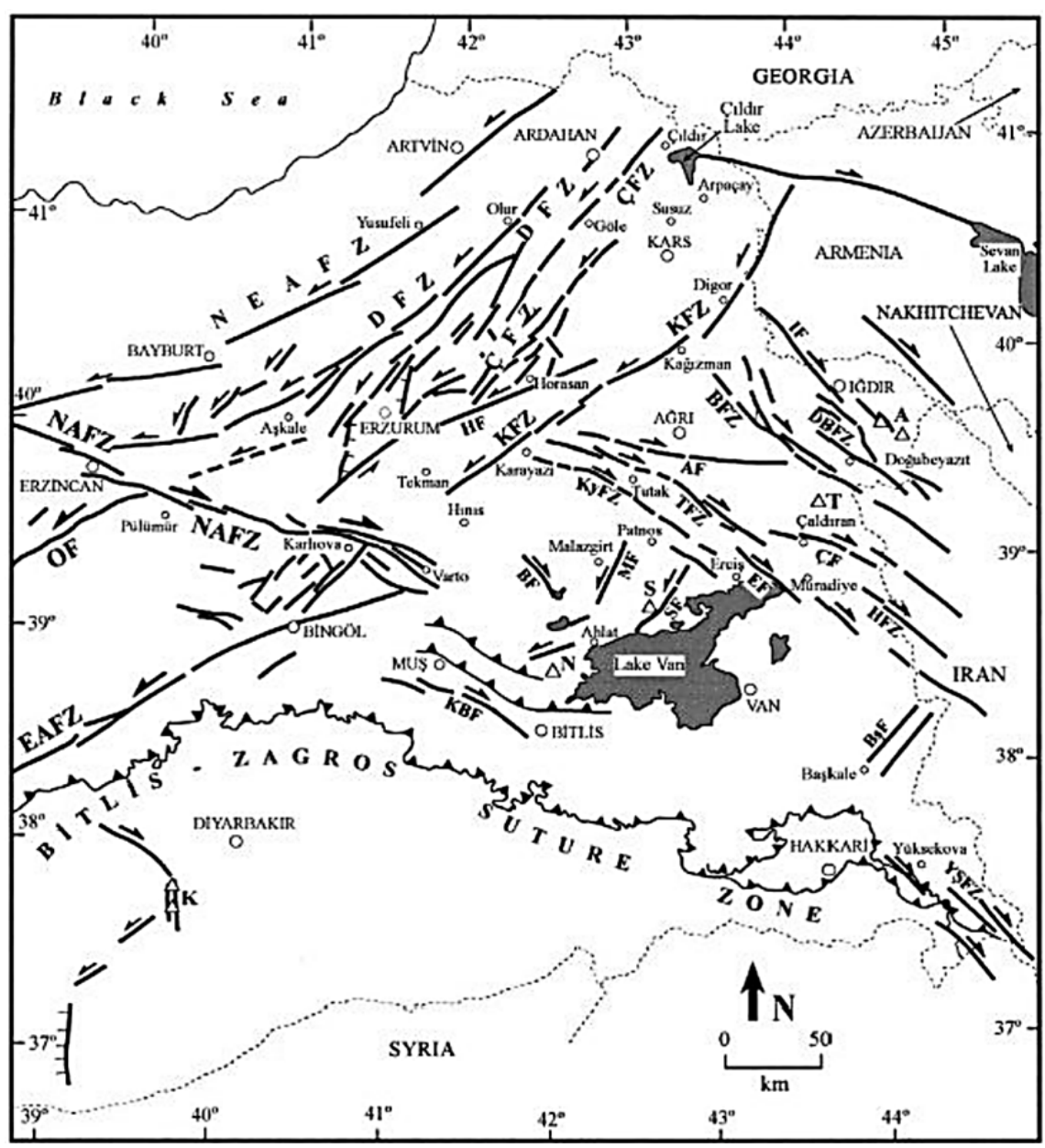

Fig. 3. Map of active faults in the Van region (Bozkurt, 2001).

plane failure. Typical examples of these types of damages are shown in Figs. 6 and 7.

A typical wall cross section in rural areas of Van is compared with a typical seismic resistant section in Fig. 8. It clearly shows how the slenderness of wythes were increased due to lack of interlocking elements.

\subsection{Connections of crossing walls}

In a seismic-resistant masonry building, crossing walls have to be interlocked properly to improve out-of-plane strength. The problem of unconnected intersecting walls is very common in the region (Fig. 9). Due to bad connection detail of the intersections, safety of the connections relied on tensile strength of the mortar used for connection. Unconnected walls were more prone to out-of-plane failures (Kaplan, et al., 2008). These types of deficiencies were not limited to external wall-partition wall intersection. At the corners of the buildings, where two external wall intersects, masonry units were not overlapped sufficiently so as to ensure an earthquake-resistant connection (Fig. 9).

\subsection{Wall openings}

Wall openings should be regular and minimized to improve earthquake resistance of URM buildings, which have lateral load resisting mechanisms provided by walls only. Many seismic design codes (MPW, 1998, 2007) provide guidelines about these openings. They restrict the distance between the two openings, distance between an opening and a corner. Plan length of an opening and ratio of length of wall openings to total wall length are also restricted by Turkish Seismic Codes. For example, the newest Turkish Seismic Code (MPW, 2007) limits the minimum distance between two openings as 1 meter for seismic zone 1 and the minimum allowable distance between an opening and a building corner is $1.5 \mathrm{~m}$.

Two examples of damages due to wall openings are given in Figs. 10 and 11. The problem in the former is the short distance between two adjacent windows. In the latter figure the problem is the short distance between the opening and the building corner. Due to this wall formation, damage was concentrated around the opening. 


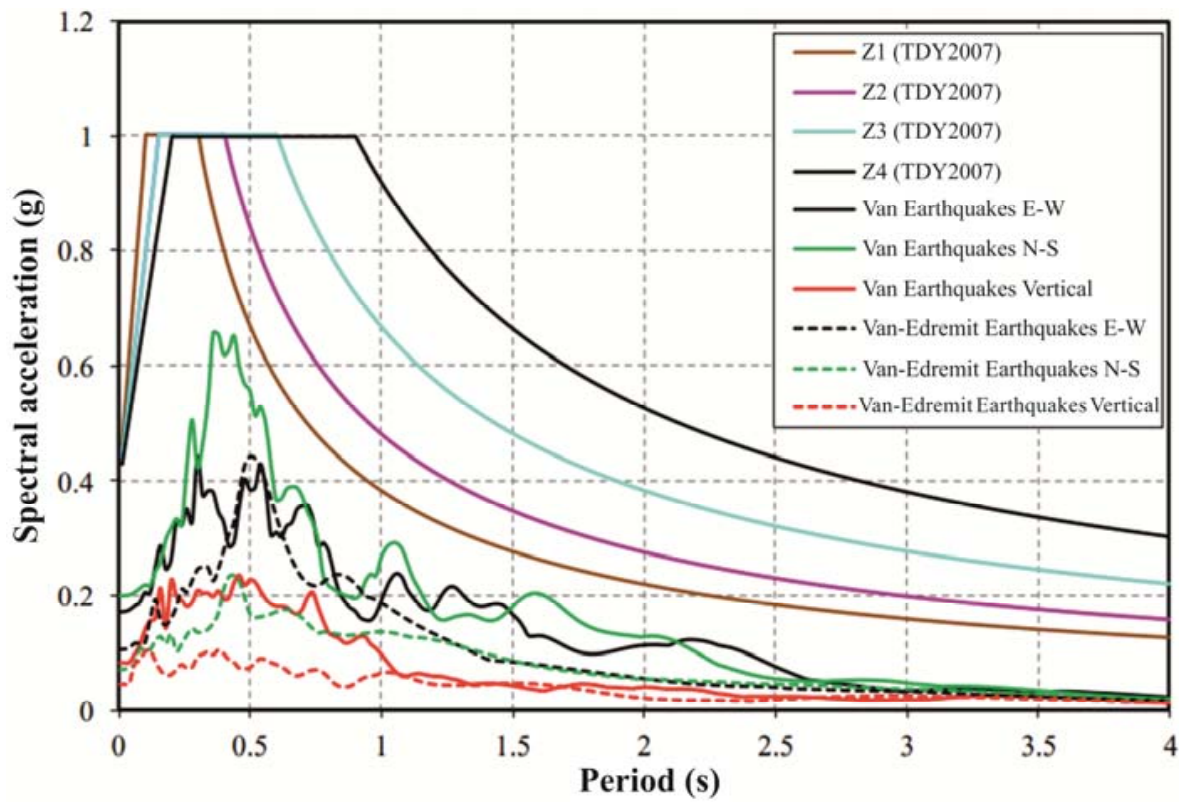

Fig. 4. Comparison of response spectra of Van-Erciş Muradiye and Van-Edremit earthquakes with design spectra (Önen et al., 2011).
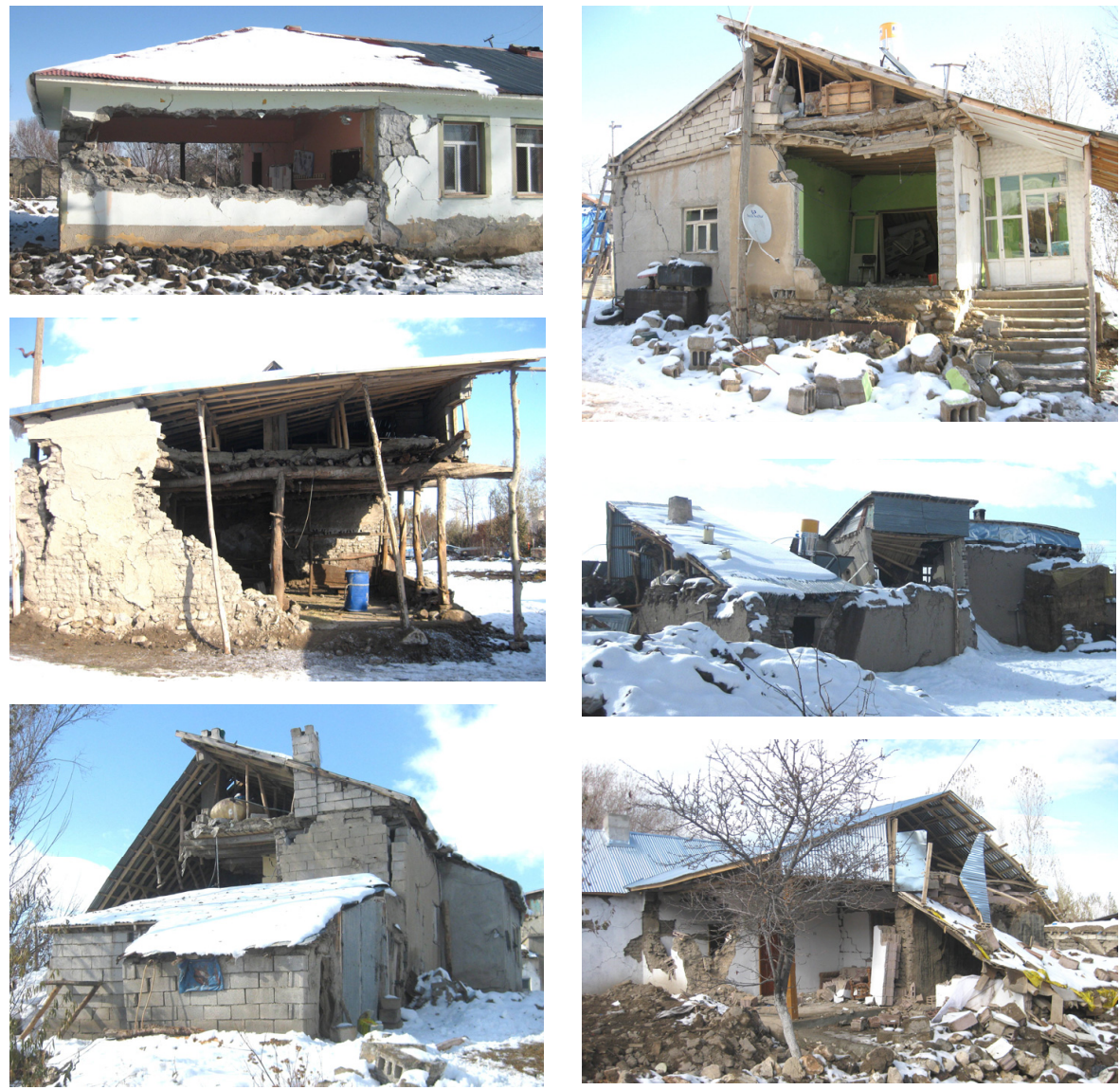

Fig. 5. Various types of damages observed at URM buildings after the 2011 Van earthquakes. 


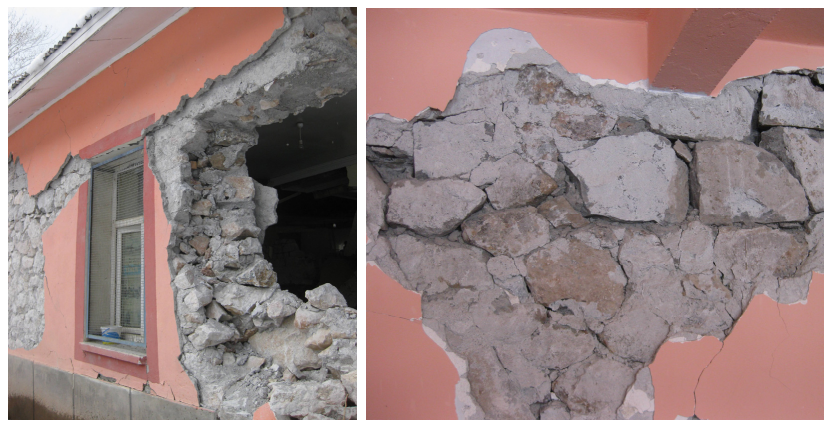

Fig. 6. Profile of a poorly constructed damaged wall.

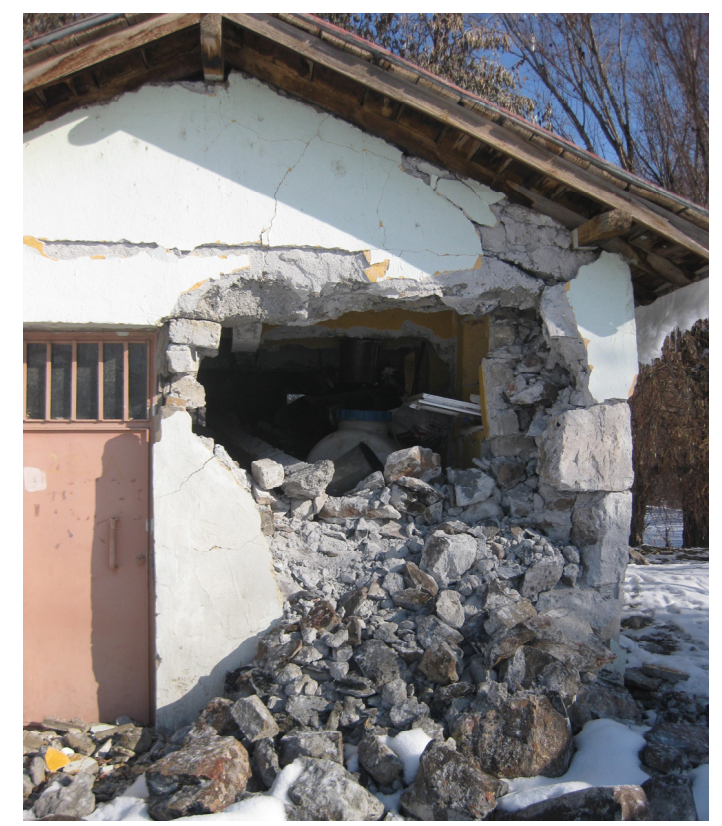

Fig. 7. Unconnected outer and inner wythes.

\subsection{Out-of-plane failures}

Out-of-plane failure is an important component of complex nonlinear masonry behavior. It may result from the combination of several deficiencies. Long, unsupported, slender walls and improper wall section formation (like unconnected inner and outer wythes) are some of those deficiencies. The lack of bonding beams at the top of the walls and light roofs with insufficient in-plane stiffness are also important reasons for this type of damage. In both cases, it is not possible to provide diaphragm effect at the roof level (Fig. 12).

An example of out-of-plane failure due to unsupported wall length is given in Fig. 13. Unsupported wall length is beyond the code limits not only due to improper partition wall configuration but also to unconnected wythes. Net length of the slender outer wythe was significantly great and it failed. This phenomenon is explained in Sect. 4.1. Besides, insufficient connections of crossing walls can also lead to failure.

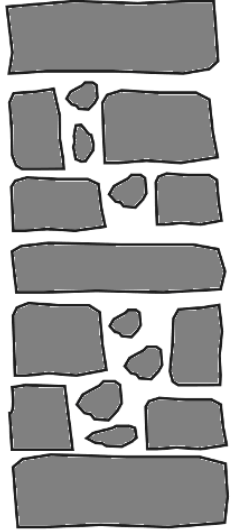

Earthquake resistant

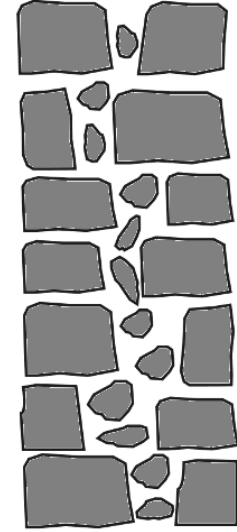

Earthquake prone
Fig. 8. Typical cross sections of earthquake resistant and fragile stone masonry walls.

Figure 9 shows that walls having damaged corner connections are more open to out of plane failure.

\subsection{Insufficient base shear capacity}

In a large portion of the investigated structures, mud was used as adhesive between wall bricks (Fig. 14) Using neither cement nor lime as adhesive decreased the cracking strength and base shear capacity of the wall. For these reasons, wall blocks were separated from each other under very small shear forces.

\subsection{Heavy roofing}

Masonry structures constructed according to engineering specifications, has adequate in-plane shear strength and therefore can stand high lateral forces. Reasons for the reduced wall strength in the investigated structures were given in previous sections.

Apart from the reasons mentioned before, the base shear demand of the structure expected in the earthquake is related to the weight of the structure. In many damaged URM structures in the earthquake region, heavy soil roofing constructed for thermal and water insulation purposes were observed (Fig. 15). For this reason, the walls which had already low lateral strength due to non-engineered construction were subjected to larger shear forces.

\section{Results and discussion}

The Van 2011 earthquakes caused extensive damages to URM structures. Results of the survey of damaged structures are presented in this paper. Most of the buildings in rural settlement areas, which were mostly comprised of one-storey URM structures, had been heavily damaged. A considerable 

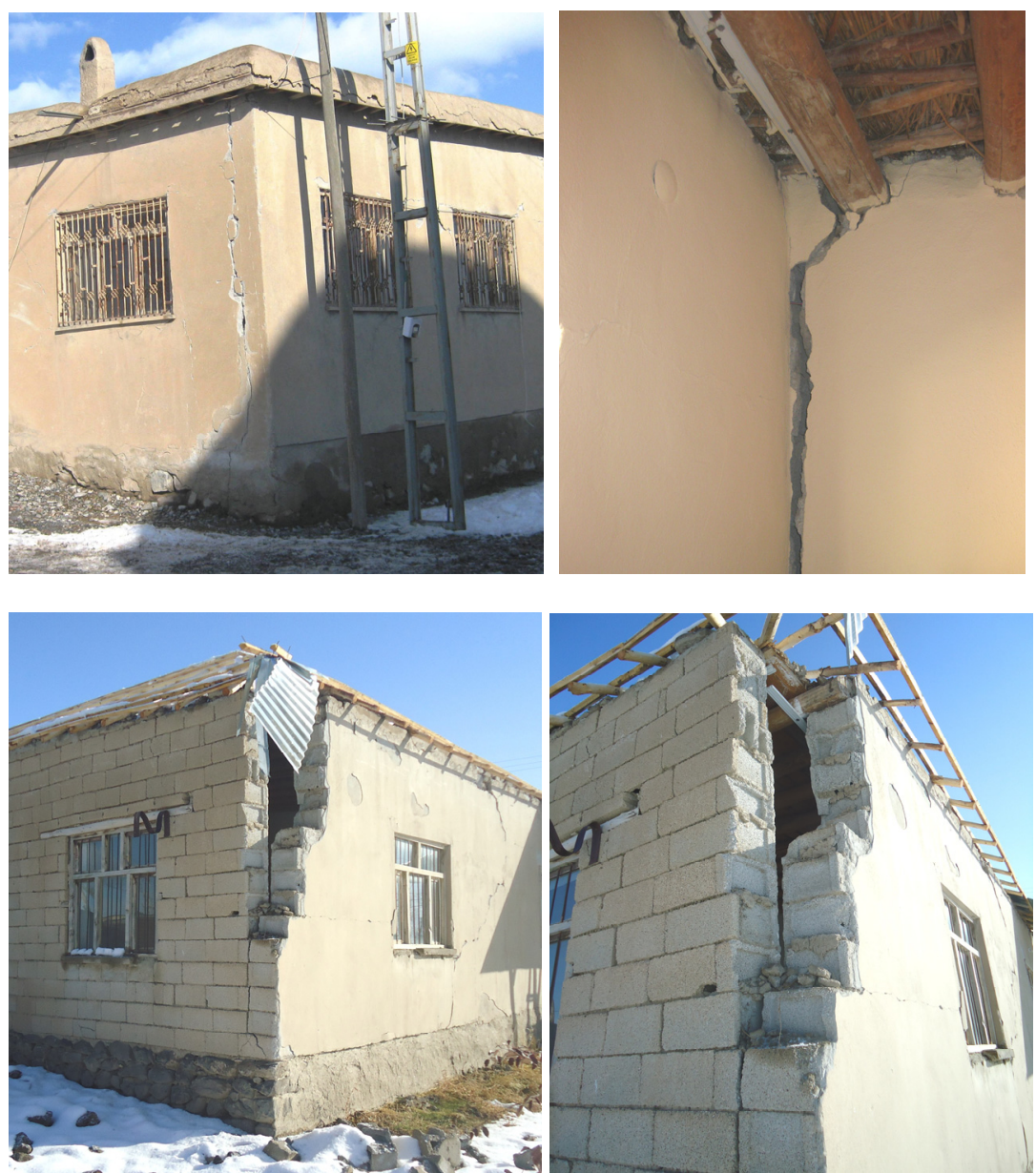

Fig. 9. Damages observed at intersection of outer walls.

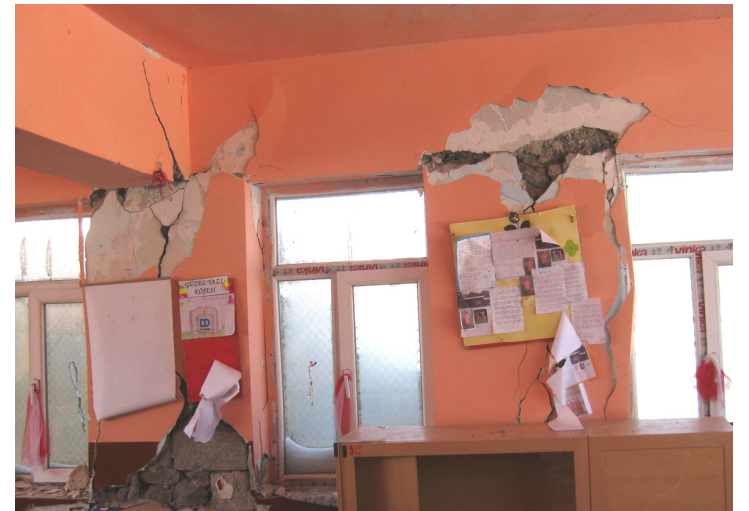

Fig. 10. Damage between two wall openings.

portion of those structures were constructed with improper masonry blocks. Materials and construction techniques of these structures did not provide any earthquake resistance.

Masonry buildings in Turkey generally have aforementioned deficiencies, due to which many URM buildings have

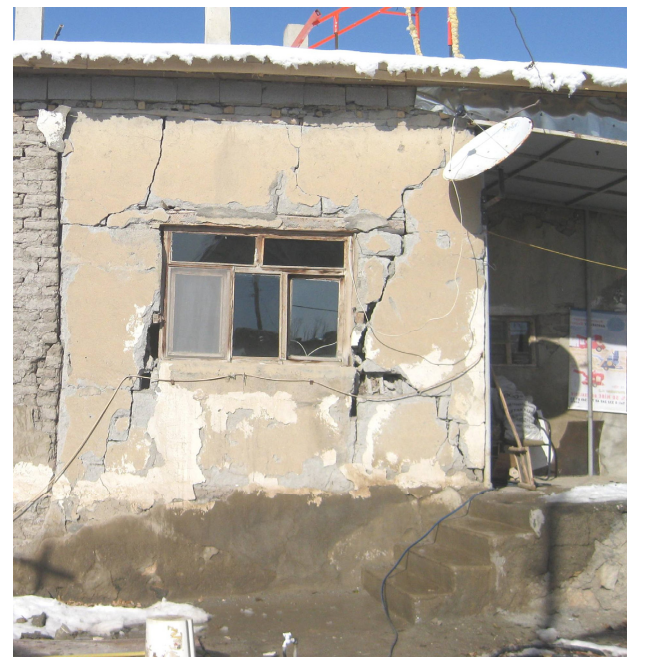

Fig. 11. Damage concentrated around wall opening near the building corner. 


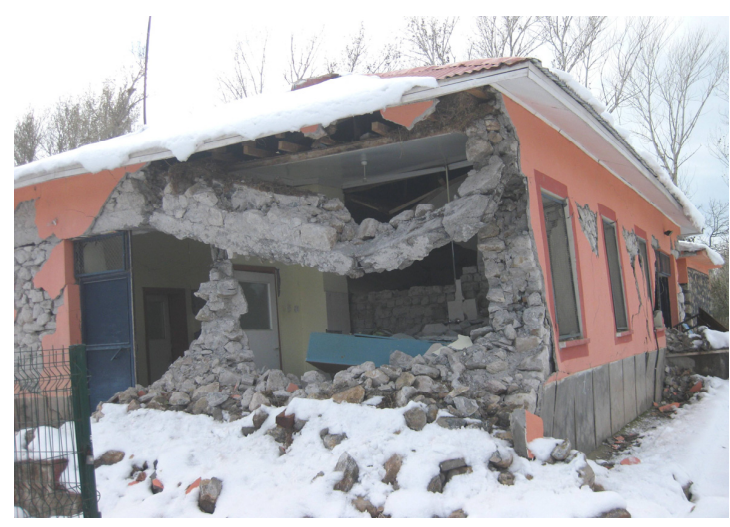

Fig. 12. Out of plane failure.

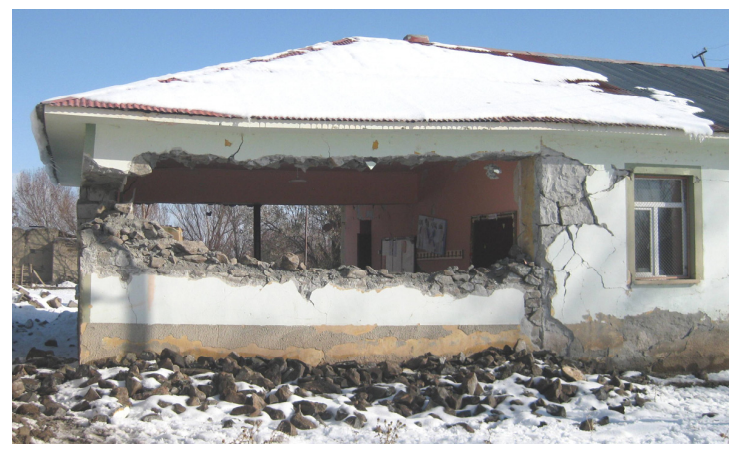

Fig. 13. Out-of-plane failure due to long unsupported wall length.

been damaged during previous earthquakes. In recent history, in addition to devastating earthquakes, even moderate events have caused damages to many non-engineered URM buildings. After the Van earthquakes, it was revealed once again that URM buildings in Turkey are highly susceptible to seismic damages, especially in rural areas, where inadequate or no engineering services are available. It is essential to take necessary precautions to reduce seismic damages in URM structures. Improvements made in construction inspection and engineering services in the last years are mostly for urban areas; rural areas and masonry structures have been neglected. The necessary laws and regulations should be established and strictly applied. Damage mitigation in rural areas should be a primary goal for Turkey.

Besides all those mentioned above, the construction of URM structures is not permitted in developed countries with high seismic risk. Masonry structures can only be constructed with reinforcement (FEMA, 2009). Allowing URM structures to be built in Turkey and many other countries is a deficiency that should be corrected. The construction of URM structures in regions with high seismic risk should not be permitted.

Edited by: M. E. Contadakis

Reviewed by: two anonymous referees
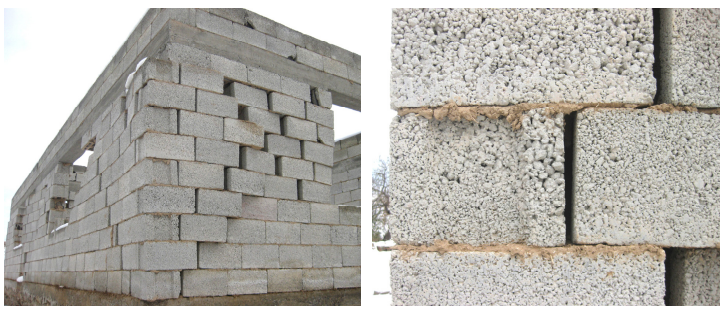

Fig. 14. Wall damage due to low strength joint adhesive.

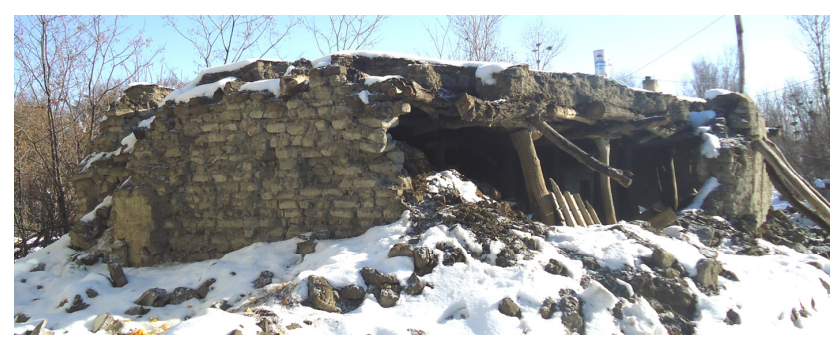

Fig. 15. Heavy roofing with soil.

\section{References}

AFAD: Earthquake Department Disaster Management and Emergency Presidency, Ankara, Turkey, www.afad.gov.tr, 2011.

Aksoy, E.: Stratigraphy and Tectonics of East-Northeast region of Van Province, Firat University, Institute of Natural Sciences, PhD thesis, Elazig, 171 pp., 1988.

Albini, P.: The true case of the 1276 Fake earthquake, Seismol. Res. Lett., 82, 1, Historical Seismologist, 2011.

Ambraseys, N.: Earthquakes in the Mediterranean and the Middle East, Cambridge University Press, 947 pp., 2009.

Bayraktar, A., Coşkun, N., and Yalçın, A.: Damages of masonry buildings during the July 2, 2004 Doğubayazit (A ğrı) earthquake in Turkey, Eng. Fail. Anal., 14, 147-157, 2007.

Berberian, M.: Seismic sources of the Transcaucasian historical earthquakes, in Historical and Prehistorical Earthquakes in the Caucasus, in: Kluwer Academic Press, The Netherlands, edited by: Giardini, D. and Balassanian, S., NATO Asi Series, Serie 2, Environment, 28, 233-311, 1997.

Bozkurt, E., Neotectonics of Turkey - a synthesis, Geodinamica Acta, 14, 3-30, 2001.

Celebi, E., Caglar, N., Ozocak, A., Aslan, H., Aktas, M., Kutanis, M., Mert, N., Ozcan, Z., and Kırtel, O.: 23 October 2011 VanErcis Earthquake Evaluation Report, Sakarya University, Adapazar 1, November, 2011.

FEMA: Federal Emergency Management Agency, Unreinforced Masonry Buildings and Earthquakes Developing Successful Risk Reduction Programs, FEMA 774, Washington DC, Federal Emergency Management Agency, 2009.

Guidoboni, E. and Comastri, A., Catalogue of Earthquakes and Tsunamis in the Mediterranean Area from the 11th to the 15th Century. Bologna, Italy: INGV-SGA, 1037 pp., 2005.

Helvac1, C. and Griffin, W. L.: Rb-Sr geochronology of the Bitlis Massif, Avnik (Bingöl) area, S. E. Turkey, in: The Geological Evolution of eastern Mediterranean, edited by: Dixon, J. E. and Robertson, A. H. F., Geol. Soc., London, Special Publications 17, 
403-413, 1984.

Kaplan, H., Yılmaz, S., Akyol, E., Sen, G., Tama, Y. S., Cetinkaya, N., Nohutcu, H., Binici, H., Atimtay, E., and Sarisin, A.: 29 October 2007, Çameli earthquake and structural damages at unreinforced masonry buildings, Nat. Hazards Earth Syst. Sci., 8, 919 926, doi:10.5194/nhess-8-919-2008, 2008.

Korkmaz, H. H., Korkmaz, S. Z., and Donduren, M. S.: Earthquake hazard and damage on traditional rural structures in Turkey, Nat. Hazards Earth Syst. Sci., 10, 605-622, doi:10.5194/nhess-10605-2010, 2010.

Karnik, V.: Seismicity of the European Area, Part I, D. Reidel, Hingham, Mass., 365 pp., 1969.

Ketin, İ.: Kurzer Bericht über die letzten Erdbeben in der Türkei. Geol. Rdsch., Bd. 35, 1947.

Kızılkanat, A., Koçak, A., Coşar, A., Güney, D., Selçuk, M. E., Yıldırım, M., Yıldız Technical University, 23 Ekim 2011 Van Earthquake Pre-evaluation Report, YTU, 2011.

KOERI: Bogazici University, Kandilli Observatory and Earthquake Research Institute, www.koeri.boun.edu.tr, 2011.

METU-EERC/ Inst. of Civil Eng., 19 November $2011 M_{\mathrm{W}}=5.6$ Van-Edremit Earthquake Observations on seismic and structural damages, Middle East Technical University, Earthquake Engineering research center, February, 2012.

MPW: Regulations for structures to be built in disaster areas, Ministry of Public Works and Settlement, Ankara, 1975 (in Turkish).

MPW: Regulations for structures to be built in disaster areas, Ministry of Public Works and Settlement, Ankara, 1998 (in Turkish).

MPW: Regulations for structures to be built in disaster areas, Ministry of Public Works and Settlement, Ankara, 2007 (in Turkish).
MTA: 1:500 000 scaled Turkey Geological Maps, Van map sheet, Mineral Research and Exploration General Directorate, Ankara, www.mta.gov.tr, 2002.

Oberhänsli, R., Candan, O., Bousquet, R., Rimmele, G., Okay, A. I., and Goff, J.: Alpine high pressure evolution of the eastern Bitlis complex, SE Turkey, Geol. Soc. London, Special Publications 340, 461-483, 2010.

Özkaymak, Ç.: Active Tectonic Properties of Van City and Close areas, Yüzüncü Yıl University, Institute of Natural Sciences, MSc thesis, 76 pp., 2003.

Önen, Y. H., Dindar, A. A., Coşgun, C., and Seçkin, E.: On -Site Investigation and Evaluation report of Van Earthquakes dated 23 October and 9 November 2011, Report No: İKÜ-CE-2011/01, TC İstanbul Kültür University, December, 2011.

Ustaömer, P. A., Ustömer, T., Collins, A. S., and Robertson, A. H. F.: Cadomian (Ediacaran-Cambrian) arc magmatism in the Bitlis Massif, SE Turkey: Magmatism along the developing northern margin of Gondwana, Tectonophysics, 473, 99-112, 2009.

Yılmaz, Y., Dilek, Y., and Işık, H.: Geology of Gevas-VAN Ophiolite and a Sinkinematic Shear Zone, Bulletin of the Turkey Geological, 24, 37-44, 1981.

Yılmaz, Y., Yiğitbaş, E., and Genç, Ş. C.: Ophiolitic and Metamorphic Assemblages of Southeast Anatolia and Their Significance in the Geological Evolution of the Orogenic Belt, Tectonics, 12 5, 1280-1297, 1993.

Yılmaz, Y., Güner, Y., and Şaroğlu, F.: Geology of the Quaternary Volcanic Centres of the East Anatolia, J. Volcanol. Geotherm. Res., 85, 173-210, 1998. 